\title{
Characterization of Penicillium Isolates Associated with Blue Mold on Apple in Uruguay
}

\author{
M. J. Pianzzola, M. Moscatelli, and S. Vero, Cátedra de Microbiología. Facultad de Química, C.P. 11800, Monte-
} video, Uruguay

\begin{abstract}
Pianzzola, M. J., Moscatelli, M., and Vero, S. 2004. Characterization of Penicillium isolates associated with blue mold on apple in Uruguay. Plant Dis. 88:23-28.

Blue mold caused by Penicillium spp. is the most important postharvest disease of apple in Uruguay. Fourteen isolates of Penicillium were recovered from rotten apple and pear fruit with blue mold symptoms, and from water from flotation tanks in commercial apple juice facilities. Phenotypic identification to species level was performed, and the isolates were tested for sensitivity to commonly used postharvest fungicides. Genetic characterization of the isolates was performed with restriction fragment length polymorphism of the region including the internal transcribed spacer (ITS) ITS1 and ITS2 and the 5.8SrRNA gene (ITS1-5.8SrRNA gene-ITS2) ribosomal DNA region and with random amplified polymorphic DNA (RAPD) primers. Both techniques were able to differentiate these isolates at the species level. RAPD analysis proved to be an objective, rapid, and reliable tool to identify Penicillium spp. involved in blue mold of apple. In all, 11 isolates were identified as Penicillium expansum and 3 as $P$. solitum. This is the first report of $P$. solitum as an apple pathogen in Uruguay.
\end{abstract}

Additional keywords: Penicillium identification

Postharvest pathogens cause major losses in apple production. More than 90 fungal species have been described as causative agents of apple decay during storage (12). Blue mold caused by Penicillium spp. is the most important postharvest disease of apple worldwide (7). In Uruguay, its control relies mainly on the use of synthetic fungicides, with thiabendazole and iprodione being the most widely used. Still, postharvest losses in our country can reach $30 \%$ of production and half of these losses are due to fungal attack (26).

Blue mold is a soft rot caused by various Penicillium spp., including Penicillium expansum, the most aggressive and the most commonly reported. Other species, such us $P$. viridicatum, $P$. brevicompactum, and $P$. solitum, also have been reported to decay apple fruit (12). P. expansum has been shown, on apple fruit, to produce patulin, a mutagenic, inmunotoxic, and neurotoxic mycotoxin (4). Therefore, it is important to detect and minimize $P$. expansum rot in apple fruit, particularly those destined for apple juice production.

Corresponding author: M. Pianzzola E-mail: mpianzzo@fq.edu.uy

This research was supported by the international Foundation for Science (IFS) from Sweden and PEDECIBA Uruguay.

Accepted for publication 6 August 2003.

Publication no. D-2003-1024-01R

(C) 2004 The American Phytopathological Society
Penicillium is a large genus, with at least 150 species, many with similar morphology (20). There also is a great deal of variability within many species, and at least 1,000 recognizably different phenotypes eventually may be catalogued. Because of the inherent variability in the genus, only 70 to $80 \%$ of isolates, even from common sources, are readily identifiable (19). Many of the taxonomic keys to identify Penicillium spp. are based primarily on morphological criteria. Most of them base identification upon micromorphology, macromorphology, and colors produced in the mycelium or diffused into the growth medium $(21,22)$. However, many authors have shown that some of these characteristics (i.e., colony texture) are highly variable and that morphological criteria do not always allow unambiguous classification $(9,10,19)$. Pitt $(19)$ stated that physiological criteria also should be considered in Penicillium spp. identification, and some investigators have used growth on nitrite or creatine as a sole nitrogen source or growth in the presence of organic acids (e.g., propionic, sorbic, and benzoic acid; $9,17,20,27)$. Furthermore, Pitt used colony diameter at selected temperatures and different media to separate sections, series, and species in the genus Penicillium $(19,20)$. Secondary metabolite profiled $(10,11)$, detection of specific enzyme activity (11), and isoenzyme electrophoretic patterns (9) also have been used to identify Penicillium spp.

More recently, genotypic characterization has proven to be very useful. Several methods for detecting DNA polymorphism in fungi have been used to detect intraspecific and interspecific variation in Penicillium and other genera $(5,6,8,14,29,30)$. These methods include restriction fragment length polymorphism (RFLP), large subunit ribosomal (r)RNA sequence, and the use of random amplified polymorphic DNA (RAPD). These studies indicate that the sensitivity and rapidity of DNA-based identification procedures greatly facilitate the development of diagnostic methods.

The present study was aimed at developing a better understanding of the isolates causing blue mold on apple in Uruguay. Numerous isolates were collected and initially characterized using phenotypic and physiological parameters. Additionally, RFLP of the internal transcribed spacer (ITS)1-5.8S to ITS2 rDNA and RAPD protocols were used to develop a simple and accurate method of species identification. Aggressiveness of the isolates also was evaluated as was their resistance to thiabendazole and iprodione.

\section{MATERIALS AND METHODS}

Strains. Penicillium strains were isolated from apple and pear fruit showing blue mold symptoms and from water from the surface of flotation tanks at two commercial juice facilities. Apple fruit utilized in this work had not been treated with synthetic fungicides after harvest.

Seventy-four water samples were analyzed. To each water sample $(100 \mathrm{ml}), 0.1$ $\mathrm{ml}$ of a $10 \%$ sodium thiosulphate solution (wt/vol) was added in order to neutralize hypochlorite. Then, $0.1 \mathrm{ml}$ of serial 10-fold dilutions was spread on $2 \%$ (wt/vol) malt agar (Oxoid) containing chloramphenicol $\left(30 \mu \mathrm{g} \mathrm{ml}^{-1}\right)$. After isolation on malt agar, monosporic cultures of each Penicillium isolate were obtained using the same medium. Terverticillated strains were selected for further study. P. expansum DSM 1994, $P$. viridicatum DSM 2447, and $P$. brevicompactum DSM 2215 were purchased from the German Collection of Microorganisms and Cell Cultures. $P$. solitum CBS 140.86 was obtained from the Centraalbureau voor Schimmelcultures (CBS, Baarn and Delft, The Netherlands). These strains were used as reference strains for our assays.

Morphological and physiological characterization. Terverticillated Penicillium isolates were identified with the aid of keys developed by Pitt (19). All isolates 
and type strains were assayed for their capacity to produce lipases, pectinases, estearases, amylases, and proteases as described by Paterson and Bridge (17). Two substrates were used to assay lipase production: trybutirine and Spirit Blue Agar supplement (Difco Laboratories, Detroit, MI). A cleared zone around the fungal colony was recorded as positive for lipase activity. Tween 80 was the substrate used to test estearase production. Growth and abundant acid production were recorded as positive for estearase activity. Casein was used to determine proteolytic activity and citrus pectin was used to induce and evaluate pectinase. Growth in glucose yeast extract agar (GYA) amended with either 50 ppm of sorbic and benzoic acids (GYBSA) or propionic acid at 1,000 ppm (GYP) also was determined and compared with growth in the same medium without preservatives (9).

The ability to grow, produce an acid reaction, and later produce basic metabolites from creatine was performed as described by Samson et al. (27). Growth on creatine agar (CREA) was compared with growth on Czapek yeast autolysate agar (CYA). Production of basic metabolites after acid production was recorded after 8 to 19 days. Change of agar color underneath the colony was recorded as positive, whereas no change of color was recorded as negative. Nitrate and nitrite $\left(3 \mathrm{~g} \mathrm{liter}^{-1}\right)$ assimilation also was assayed $(9,17)$. All assays were evaluated after 7 days of incubation at $25^{\circ} \mathrm{C}$, except where specified. Growth on water agar was evaluated as a negative control.

Quantitative assessment of fungicide sensitivity. Minimal inhibitory concentration (MIC) of thiabendazole and iprodione were determined for native isolates. Conidia on 4- to 5-day old potato-dextrose agar (PDA) slant cultures were suspended in $5 \mathrm{ml}$ of sterile water containing $0.1 \%$ Tween 80, agitated for 5 to $10 \mathrm{~s}$, and filtered through double-layered cheesecloth to remove hyphal fragments. The suspension was adjusted to $10^{4}$ conidia/ml and 10 $\mu \mathrm{l}$ of suspension was inoculated onto 200 $\mu \mathrm{l}$ of PDA amended with different fungicide concentrations dispensed into the wells of sterile, disposable, 96-well microtiter plates (Montegrotto Terme, Padova, Italy). After $72 \mathrm{~h}$ of incubation at $25^{\circ} \mathrm{C}$ in darkness, fungal growth was determined visually. MIC was defined as the lowest concentration that inhibited fungal growth. Two repetitions per treatment were performed. Fungicide concentrations assayed were $0,0.5,1,2,4,8,16,32,64,128,256$, and $512 \mathrm{ppm}$. Experiments were repeated at least twice.

Formulated fungicides were used for these experiments. For iprodione, we used Rovral 50 WP (Rhône Poulenc, Lyon, France), and for thiabendazole we used Tecto 500 SC (500 g liter ${ }^{-1}$; Syngenta International AG, Basel, Switzerland). The amount of formulated fungicide added to the medium was calculated to reach the concentrations of active ingredients specified above.

Secondary metabolite profiles. Secondary metabolite profiles from all isolates were determined by thin-layer chromatography (TLC) as described by Paterson and Bridge (17). From pure cultures grown on yeast extract sucrose agar (YES) for 7 days at $25^{\circ} \mathrm{C}$ in the dark, metabolites were transferred to the TLC plates by consecutively placing three agar plugs per culture, medium side down, for $30 \mathrm{~s}$ on each spot. Patulin (Sigma-Aldrich, St. Louis, MO) also was applied to plates as a reference. TLC plates used in this assay were precoated with silica gel containing fluorescent indicator $\mathrm{UV}_{254}$ (Macherey-Nagel, Düren, Germany). Plates were developed in ascending mode in a chamber with toluene:ethyl acetate:formic acid (6:3:1) as the mobile phase. After being air dried, plates were visualized under UV light $(254 \mathrm{~nm})$. Results were evaluated by TLC scanning densitometry at $275 \mathrm{~nm}$ with a TLC scanner (model 9300; Shimadzu, Tokyo) operated in zigzag mode. After scanning, plates were sprayed with a $0.5 \%$ aqueous solution of 3-methyl-2-benzothiazolinone hydrazone hydrochloride hydrate (MBTH), heated at $130^{\circ} \mathrm{C}$ for $5 \mathrm{~min}$, then scanned at $412 \mathrm{~nm}$ to confirm patulin presence (31).

Aggressiveness evaluation. Aggressiveness of native strains was determined by measuring the diameter of lesions induced on apple fruit after wound inoculation. Mature apple fruit (cv. Red Delicious) were surface disinfected with $1 \%$ hypochlorite, then rinsed twice with sterile water. Each fruit was wounded with a cork borer $(6 \mathrm{~mm}$ in diameter, $5 \mathrm{~mm}$ deep) at three locations at the equatorial region. Each wound was inoculated with $40 \mu \mathrm{l}$ of conidial suspensions $\left(10^{6}\right.$ conidia $\left.\mathrm{ml}^{-1}\right)$ from 7-day-old Penicillium cultures. Inoculated fruit were placed in separate polyethylene bags and incubated at $5^{\circ} \mathrm{C}$. After 21 days at $5^{\circ} \mathrm{C}$, lesion diameters were measured and recorded. Nine repetitions per treatment were carried out and the experiment was repeated twice. Lesion diameters were compared by analysis of variance using the GLM procedure of SAS (release 6.12 SAS/STAT, 1996; SAS Institute, Cary, NC). Sources of variation in the experiment for lesion growth rate were species and isolates. Similarity matrices were constructed from the mean and standard deviation of the lesion diameters using Crovello's taxonomic distance (28). Dendrograms were constructed based on the unweighted pair-group method using arithmetic average (UPGMA) with NTSYS-pc version 1.80 (24).

Fungal growth conditions and DNA extraction. Fungal mycelium was cultivated at $24^{\circ} \mathrm{C}$ for 5 days in liquid YES medium, harvested by filtration, and ground in liquid $\mathrm{N}_{2}$ with a sterile mortar and pestle. Aliquots of approximately 50 $\mathrm{mg}$ were extracted using the method of Raeder and Broda (23). DNA was resuspended in $80 \mu \mathrm{l}$ of sterile distilled water and heated at $65^{\circ} \mathrm{C}$ for $15 \mathrm{~min}$. DNA concentration was estimated by means of absorbance at $260 \mathrm{~nm}$.

Polymerase chain reaction amplification for RFLP studies. Polymerase chain reaction (PCR) was performed with an automated temperature cycling device (model 2400; Perkin-Elmer, Foster City, CA). PCR fragments were generated using primers ITS4 and ITS5 (32) covering the ITS 1-5.8S and ITS 2 region of the rDNA, synthesized by the BYO.SYNTHESIS Company (Lewisvile, TX). Ready-to-Go PCR Beads (Amersham Pharmacia Biotech, Piscataway, NJ) were used for amplification reactions. Amplifications were performed with an initial denaturation step for $2 \mathrm{~min}$ at $94^{\circ} \mathrm{C}$, followed by 35 cycles $(1$ cycle consists of denaturation for $40 \mathrm{~s}$ at $95^{\circ} \mathrm{C}$, annealing for $1 \mathrm{~min}$ at $54^{\circ} \mathrm{C}$, and extension for $2 \mathrm{~min}$ at $72^{\circ} \mathrm{C}$ ), with a final extension of $10 \mathrm{~min}$ at $72^{\circ} \mathrm{C}$.

Restriction enzyme analysis. PCR products $(10 \mu \mathrm{l})$ were digested with the restriction enzymes HinfI (Amersham Pharmacia Biotech) and TaqI (Biolabs, Boston) and the reactions were incubated overnight at 37 and $65^{\circ} \mathrm{C}$ respectively. The DNA fragments were resolved by electrophoresis in 3\% agarose Metaphor and photographed over UV light. Ethidium bromide was added to the gels prior to electrophoresis.

RAPD fingerprinting. Ready-to-Go PCR Beads (Amersham Pharmacia Biotech) were used for amplification reactions. The DNA (10 ng), the corresponding primer $(25 \mathrm{pmol})$, and sterile distilled water were added to a final volume of $25 \mu$ l. Twenty-decamer oligonucleotide primers initially were screened against genomic DNA of Penicillium type strains. One of these primers was selected on the basis of clearly discernible polymorphic bands. The sequence of this primer was $5^{\prime}$ TGCCGAGCTG 3' (13). Amplifications were carried out in a Perkin-Elmer 2400 Thermal Cycler (Perkin-Elmer). The initial denaturation at $96^{\circ} \mathrm{C}$ for $8 \mathrm{~min}$ was followed by 35 cycles of $96^{\circ} \mathrm{C}$ for $1 \mathrm{~min}$, $34^{\circ} \mathrm{C}$ for $2 \mathrm{~min}, 72^{\circ} \mathrm{C}$ for $2.5 \mathrm{~min}$, and a final extension at $72^{\circ} \mathrm{C}$ for $10 \mathrm{~min}$. A $10-\mu \mathrm{l}$ volume of each reaction was analyzed by electrophoresis on a 1.5\% agarose Metaphor gel (Karlan Research Company Corporation, Santa Rosa, CA) in 1× Tris-borateEDTA buffer at $5 \mathrm{~V} / \mathrm{cm}$ and stained with ethidium bromide. Gels were photographed over UV light using a DC120 Zoom Digital Camera (Kodak Digital Science, Rochester, $\mathrm{NY}$ ) and converted into a tagged image file format using Electrophoresis Documentation and Analysis System 120 (Eastman Kodak Company, Rochester, NY).

RAPD band profiles were analyzed with the pattern analysis software package Gel- 
Compar (version 4.2; Applied Maths, Kortrijk, Belgium). Electrophoresis data were recorded as a binary presence or absence matrix, without taking the intensity of the bands into account. Similarity matrices were constructed from the binary data with Jaccard's coefficients. Dendrograms were constructed based on UPGMA. To check the reliability of the method, DNA extraction and purification, RAPD amplification, and gel analysis were performed twice by different operators using two different thermocycler devices.

\section{RESULTS}

Isolate identification and characterization. All 14 terverticillated Penicillium strains collected were capable of causing blue mold on Red Delicious apple fruit. Using identification keys developed by Pitt (19) and the criteria described below, 11 of these isolates were identified as $P$. expansum and the other 3 as $P$. solitum, which recently has been recognized as a pathogen on apple (19). Six of the P. expansum strains were isolated from flotation tanks at commercial juice facilities. The other $P$. expansum strains and all $P$. solitum strains came from apple fruit showing blue mold symptoms (Table 1). Fungicide resistance was detected in isolates belonging to both species. More than $50 \%$ of the P. expansum strains and all $P$. solitum strains were resistant to thiabendazole. Only one $P$. expansum strain showed high resistance to iprodione. The results for some of the physiological and morphological tests also are shown in Table 1. Only characteristics that differed among the tested strains are shown. Estearase, amylase, and pectinases were produced by all the strains. Growth and acid production rates on CREA and growth in media amended with sorbic and benzoic acids were homogeneous within a species, but some interspecific differences were observed. All other tests showed diversity among strains within a species and, therefore, could not be used for species identification. The macromorphology of $P$. expansum isolates in CYA also was highly variable. Differences in texture, reverse colors, and the extent of sporulation were observed within isolates of $P$. expansum. This variation was not observed for $P$. solitum isolates, which developed very similar colonies on CYA at $25^{\circ} \mathrm{C}$.

Results of the aggressiveness tests at $5^{\circ} \mathrm{C}$ indicated that both $P$. solitum and $P$. expansum produced significantly different lesion diameters on apple fruit $(P=0.01)$. Four clusters could be defined by the dendrogram (Fig. 1). One cluster is formed by $P$. solitum isolates, whereas $P$. expansum isolates could be grouped into three clusters.

Not all of the strains belonging to the same species showed the same profile of secondary metabolites. Although all $P$. solitum strains exhibited almost identical chromatograms, $P$. expansum strains showed two different profiles. Two of the analyzed $P$. expansum strains did not produce detectable amounts of patulin in the assayed conditions. Chromatograms corresponding to $P$. solitum secondary metabolites indicated the presence of a compound with the same Rf as patulin at $275 \mathrm{~nm}$. Spots corresponding to both compounds also were very similar in color when visualized at $254 \mathrm{~nm}$. However, the use of MBTH revealed that the compound produced by $P$. solitum strains was not patulin. None of the strains of the other Penicillium spp. tested produced this mycotoxin (Table 1).

RAPD fingerprinting. Based on preliminary tests, only 1 of the 20 initially selected RAPD primers was chosen based on its capacity to reveal polymorphisms among the different species of terverticillated Penicillium tested. This primer gave reproducible RAPD patterns, with $13 \%$ being the highest difference in band presence between repetitions for the same isolate. With this primer, two different and very homogeneous patterns were revealed for natural isolates which corresponded to those of $P$. expansum and $P$. solitum type strains. Little intraspecific variability was evident. The RAPD band patterns corresponding to $P$. expansum and $P$. solitum isolates showed up to $78 \%$ similarity, whereas those corresponding to the closest related species ( $P$. expansum and $P$. viridicatum) showed similarity levels of about $68 \%$. Dendogram analysis of the RAPD profiles (Fig. 2) showed two clustered groups well differentiated corresponding to $P$. expansum isolates, whereas all native $P$. solitum isolates could be grouped together in a separated cluster.

RFLP studies. The PCR products amplified with the primers ITS4 and ITS5 of the 18 strains tested had a similar size of about $600 \mathrm{bp}$. The restriction profiles in electrophoresis gels are shown in Figures 3 and 4.

\section{DISCUSSION}

The present study indicates that two terverticillated Penicillium spp., P. expansum and $P$. solitum, both are causative agents of apple storage decay in Uruguay.

Table 1. Physiological characteristics and fungicide minimal inhibitory concentration (MIC) for Penicillium strains used in this study ${ }^{\mathrm{u}}$

\begin{tabular}{|c|c|c|c|c|c|c|c|c|c|c|c|c|c|c|c|}
\hline \multirow[b]{2}{*}{ Strains $^{w}$} & \multicolumn{3}{|c|}{ CREA $^{v}$} & \multicolumn{2}{|c|}{ Lipase } & \multirow[b]{2}{*}{ Pro } & \multirow[b]{2}{*}{ Tw 80} & \multirow[b]{2}{*}{$\mathrm{NO}_{2}^{-} \mathrm{x}$} & \multirow[b]{2}{*}{$\mathbf{G Y P}^{\mathbf{z}}$} & \multirow[b]{2}{*}{ GYBS $^{\mathrm{z}}$} & \multirow[b]{2}{*}{ Crys. $^{\mathbf{x}}$} & \multirow[b]{2}{*}{ Citric } & \multirow[b]{2}{*}{ Patulin } & \multicolumn{2}{|c|}{ MIC (ppm) } \\
\hline & Gr. $^{\mathbf{x}}$ & Acid $^{y}$ & Basic & Trib. & S.B. & & & & & & & & & TBZ & Ipro. \\
\hline P. expansum DSM 1994 & ++ & ++ & + & - & - & + & + & - & ++ & ++ & ++ & ++ & + & nd & nd \\
\hline P. expansum 2 (a) & ++ & ++ & + & - & - & + pig & + & - & ++ & ++ & ++ & + & + & $<0.5$ & $<0.5$ \\
\hline P. expansum 3 (a) & ++ & ++ & + & - & - & + & \pm & - & ++ & ++ & + & + & + & $<0.5$ & $<0.5$ \\
\hline P. expansum 4 (a) & ++ & ++ & + & + & - & + pig & + & - & ++ & ++ & ++ & + & - & $<0.5$ & $<0.5$ \\
\hline P. expansum 10 (a) & ++ & ++ & + & - & + & + & + & ++ & ++ & ++ & ++ & + & + & $>512$ & $<0.5$ \\
\hline P. expansum 12 (b) & ++ & ++ & + & + & + & + & + & - & ++ & ++ & - & + & - & $>512$ & $<0.5$ \\
\hline P. expansum 13 (b) & ++ & ++ & + & + & + & + & + & - & ++ & ++ & - & + & + & $>512$ & $<0.5$ \\
\hline P. expansum 14 (b) & ++ & ++ & + & + & + & + & + & - & ++ & ++ & + & + & + & $>512$ & $<0.5$ \\
\hline P. expansum 15 (c) & ++ & ++ & + & - & + & + & + & - & ++ & ++ & + & + & + & $>512$ & 256 \\
\hline P. expansum 16 (c) & ++ & ++ & + & - & + & + & ++ & - & ++ & ++ & + & + & + & $>512$ & $<0.5$ \\
\hline P. expansum 17 (c) & ++ & ++ & + & - & + & + & + & - & ++ & ++ & + & + & + & $<0.5$ & $<0.5$ \\
\hline P. expansum 19 (a) & ++ & ++ & + & - & - & + & \pm & - & ++ & ++ & + & + & - & $<0.5$ & 4 \\
\hline P. solitum $\mathrm{CBS} 140.86$ & + & + & + & + & $\ldots$ & + & + & - & ++ & + & - & + & - & nd & nd \\
\hline P. solitum 7 (a) & + & + & + & - & - & + pig & + & + & + & + & + & ++ & - & $>512$ & 8 \\
\hline P. solitum 8 (c) & + & + & + & - & - & + & + & - & + & + & + & - & - & $>512$ & $<0.5$ \\
\hline P. solitum 9 (b) & + & + & + & - & - & + & + & - & + & + & + & - & - & $>512$ & 16 \\
\hline P. viridicatum DSM 2447 & - & - & - & + & - & + & nd & - & - & ++ & - & nd & - & nd & nd \\
\hline P. brevicompactum DSM 2215 & - & - & - & + & - & + & nd & - & - & ++ & - & nd & - & nd & nd \\
\hline
\end{tabular}

${ }^{\mathrm{u}} \mathrm{Gr}=$ growth, Trib. $=$, S.B. $=$, Tw $80=$ Tween $80, \mathrm{GYP}=$ glucose yeast extract agar $(\mathrm{GYA})$ amended with propionic acid at $1,000 \mathrm{ppm}, \mathrm{GYBS}=\mathrm{GYA}$ amended with $50 \mathrm{ppm}$ of sorbic and benzoic acids, Crys. $=$ crystal violet, Citric $=$ citric acid, $\mathrm{TBZ}=$ thiabendazole, Ipro. $=$ Iprodione, pig $=$ pigment, $\mathrm{nd}$ $=$ not determined.

${ }^{\mathrm{v}} \mathrm{CREA}=$ creatine agar.

${ }^{\mathrm{w}}$ Isolated from water from flotation tanks (a), pear fruit (b), or apple fruit (c).

$\mathrm{x}++=$ Growth nearly as on Czapek yeast autolysate agar (CYA), $+=$ growth weaker than on CYA agar, and $-=$ growth as on water agar.

$\mathrm{y}++=$ Abundant acid production and $+=$ acid production just underneath the colony.

${ }^{\mathrm{z}}++=$ Growth nearly as on GYA, $+=$ growth weaker than on GYA, and $-=$ growth as on water agar. 

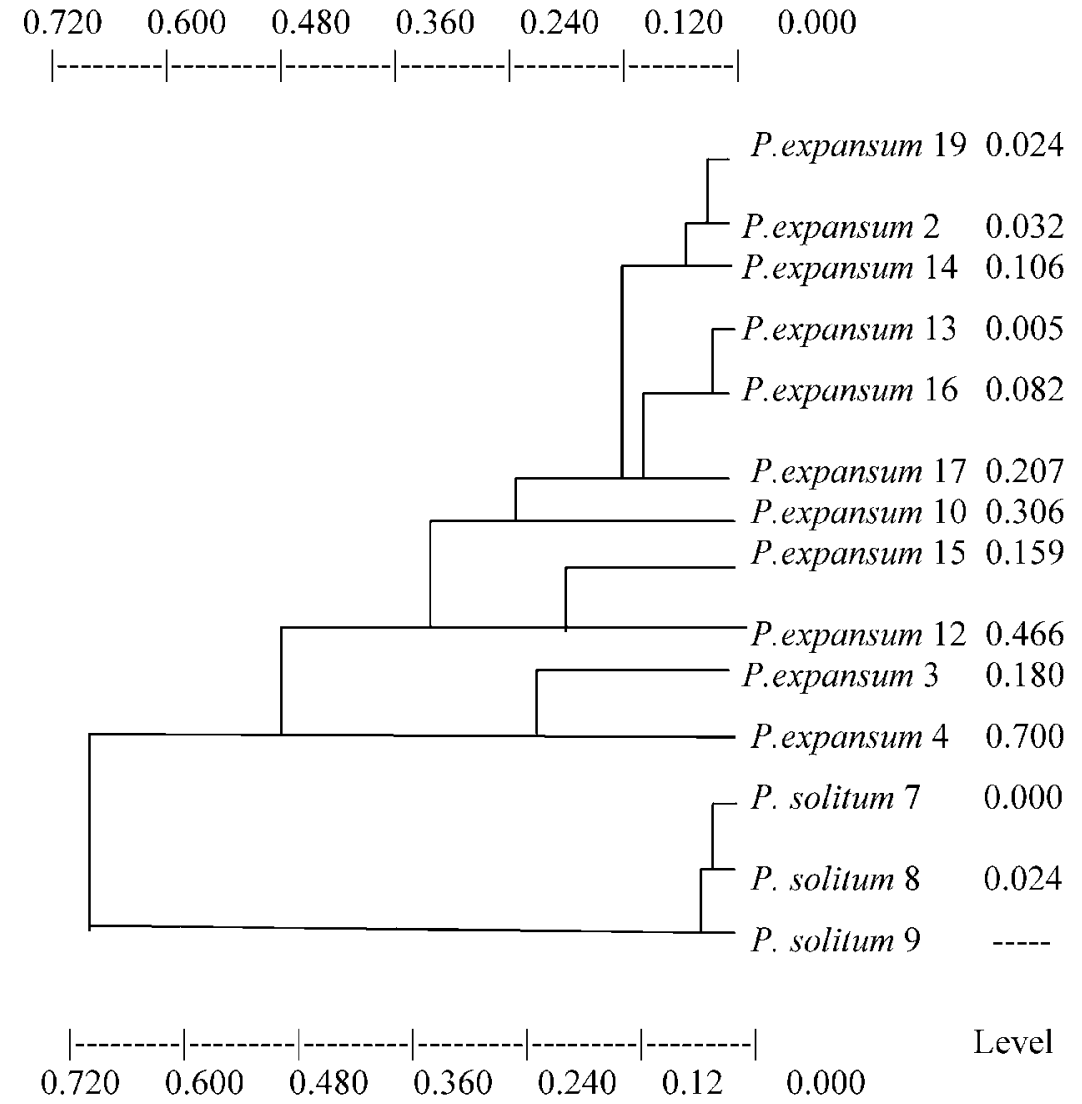

Level

Fig. 1. Unweighted pair-group method using arithmetic average dendrogram of aggressiveness of Penicillium expansum and $P$. solitum isolates.

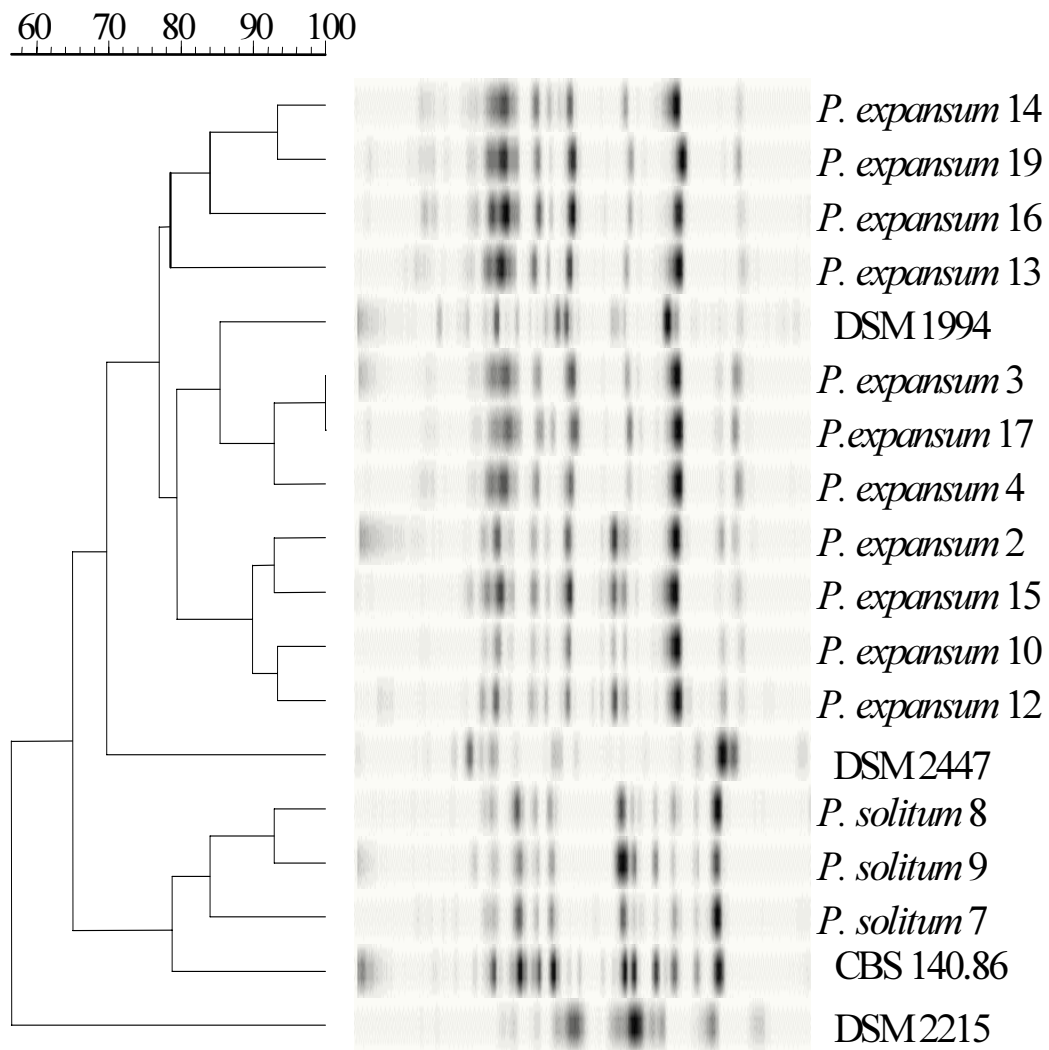

Fig. 2. Unweighted pair-group method using arithmetic average dendrogram of random amplified polymorphic DNA, 7 fingerprints from 14 terverticillated Penicillium isolates. The percentage of genetic homology between banding patterns is indicated. Reference strains: Penicillium expansum DSM1994, P. solitum CBS 140.86, P. viridicatum DSM2447, and P. brevicompactum DSM 2215.
P. expansum is the more aggressive species and is the most frequently associated with blue mold losses during apple storage in Uruguay and worldwide $(12,25)$. P. solitum also has been reported as an apple pathogen (19), but this is the first report of this pathogen in Uruguay. The identification and characterization of $P$. solitum as a casual agent of blue mold cannot be interpreted as an isolated event because the isolates came from different sources and showed distinct phenotypic differences when compared with isolates of $P$. expansum. Resistance to the most commonly used fungicides was demonstrated for strains of both species of pathogens. High levels of resistance to thiabendazole could be explained by the broad, long-term use of this fungicide in Uruguay. Thiabendazole is used not only in postharvest drenches but also in field treatments to control apple scab caused by Venturia inaequalis (2). This fungicide has a specific action site and frequent use can increase the risk of developing resistance (15). Resistance to iprodione was demonstrated principally for $P$. solitum strains, which also showed resistance to thiabendazole. High resistance levels to benzimidazoles and diphenylamines already have been demonstrated for $P$. solitum isolates in the United States (24). These results indicate the need for alternative methods or resistant management strategies to control blue mold.

Secondary metabolite analysis revealed both interspecific and intraspecific differences (e.g., patulin was not produced by all $P$. expansum isolates). TLC analysis was a simple screening method for analyzing secondary metabolites but, due to the intraspecific differences, the method could not be used as a sole identification tool. Moreover, Boysen et al. (3) pointed out that the method was dependent on the substrate used for secondary metabolites production; therefore, identification based only on individual secondary metabolites could be misleading. Other phenotypic parameters examined showed interspecific differences and were very useful to differentiate terverticillated Penicillium spp. involved in apple rot. The most useful ones were colony growth rates on CYA and on CREA, at $25^{\circ} \mathrm{C}$, acid production on CREA, and behavior in the presence of organic acids. The results of these assays were objective and easy to record, but required at least 7 days to obtain. Despite its usefulness, phenotypic identification involves a set of different time-consuming and laborintensive tests. This represents a major drawback for this approach to identification. Moreover, all phenotypic assays are dependent on gene expression; therefore, it is very important to standardize the procedures to obtain reproducible results.

The application of genotype (DNA)based systems could overcome the drawbacks of phenotypic and physiological methods of taxonomic identification. RFLP 


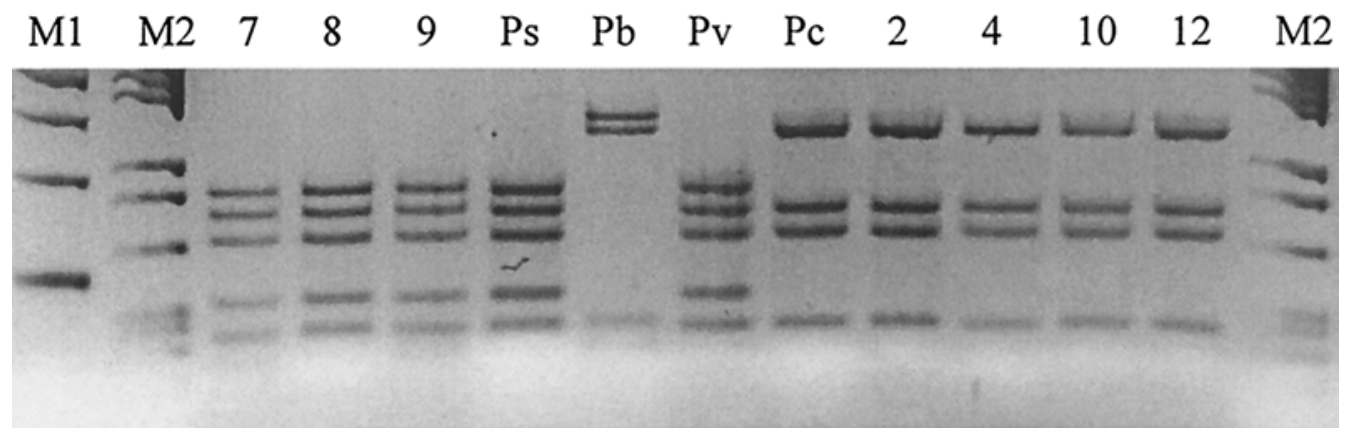

Fig. 3. Restriction patterns of polymerase chain reaction-amplified internal transcribed spacer regions digested with $T a q \mathrm{I}$ obtained by $3 \%$ agarose gel electrophoresis. Lanes: M1, 100-bp molecular weight marker; M2, pGEM marker; 7, 8, and 9, Penicillium solitum isolates; Ps, P. solitum CBS 140.86; Pb, P. brevicompactum DSM 2215; Pv, P. viridicatum DSM 2447; Pc, P. expansum DSM 1994; 2, 4, 10, and 12, P. expansum isolates.

$\begin{array}{lllllllllllllllll}\mathrm{M} 1 & \mathrm{M} 2 & \mathrm{Pc} & \mathrm{Pb} & \mathrm{Ps} & \mathrm{P} 7 & \mathrm{PC} & \mathrm{AN} & \mathrm{P} 2 & \mathrm{P} & \mathrm{P} 10 & \mathrm{P} 12 & \mathrm{P} 16 & \mathrm{P} 17 & \mathrm{Pv} & \mathrm{M} 1\end{array}$

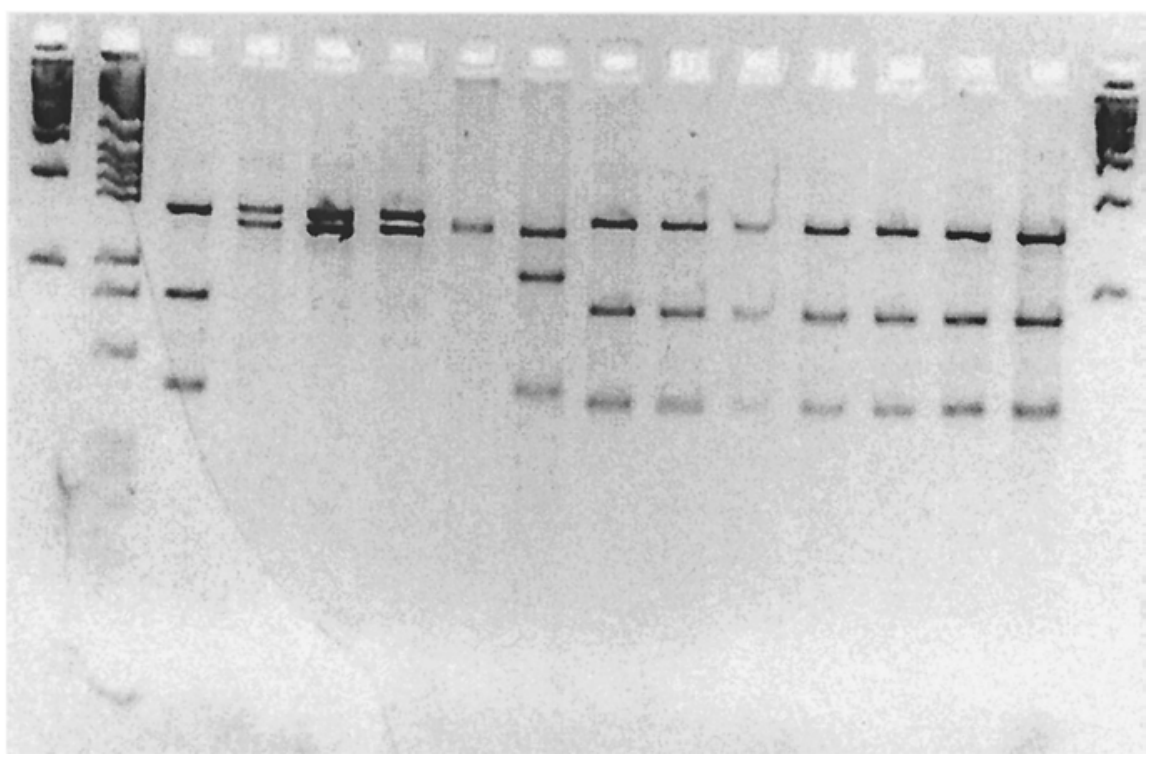

Fig. 4. Restriction patterns of polymerase chain reaction-amplified internal transcribed spacer regions digested with HinfI obtained by $3 \%$ agarose gel electrophoresis. Lanes: M1, 100-bp molecular weight marker; M2, pGEM marker; Pc, Penicillium expansum DSM 1994; Pb, P. brevicompactum DSM 2215; Ps, P. solitum CBS 140.86; P7, P. solitum isolate; PC, P. chrisogenum; AN, Aspergillus niger; P2, P4, P1, P12, P16, and P17, P. expansum isolates; Pv, P. viridicatum DSM 2447.

of the ITS1-ITS2 region with two enzymes revealed enough variation to distinguish among four species. With the use of HinfI, $P$. solitum and $P$. brevicompactum could be distinguished from $P$. viridicatum and $P$. expansum. The use of TaqI allowed differentiation between $P$. expansum and $P$. viridicatum, and between $P$. solitum and $P$. brevicompactum. The use of the two enzymes separately resulted in unique patterns for each species. The taxonomic information recoverable from ITS regions often can give sufficient information, but it is not advisable to use these sequences as the only criteria for identification (3). A point mutation could result in different profiles. Moreover, when comparing ITS15.8S rRNA-ITS2 sequences from $P$. expansum (AJ270767) and $P$. viridicatum (AJ005482) from Genbank, it is possible to detect high similarity of both sequences. In fact, there are only three differences between their sequences, one of which corresponds to the restriction site of TaqI, indi- components. The use of prepacked beads allowed us to obtain reproducible band patterns and decreased the risk of contamination. Under accurate PCR conditions, the RAPD method was shown to be reproducible, non-labor intensive, and result in objective data.

Numerical analysis of profiles obtained with the selected RAPD primer showed very limited intraspecific diversity among the isolates and allowed clear differentiation of terverticillated Penicillium spp. involved in apple rot. We suggest that the RAPD technique is a rapid and reliable tool to distinguish the Penicillium spp. tested. It would be useful to perform this characterization for some other terverticillated Penicillium spp. in order to determine the general application of the method. It also would be valuable to identify fragments for the synthesis of RAPD-derived probes for subsequent PCR amplification tests for the specific detection of the studied Penicillium spp., as RAPD cannot be used to detect fungi in mixed samples. This would make possible the identification of fungi in infected fruit or in the presence of other contaminant organisms.

\section{ACKNOWLEDGMENTS}

We thank M. Wisniewski for the critical reading and correction of this manuscript.

species. These species, however, could be clearly separated by RAPD. This could be due to the amplification of multiple bands corresponding to coding and noncoding regions dispersed throughout the genome, whereas PCR-RFLP analysis provides information for a specific region.

The RAPD technique used in this work offers several advantages for typing studies. It is simple and easy to perform; therefore, large numbers of isolates can be analyzed in a few days. It also was sensitive enough to detect intra- and interspecies differences. Importantly, reproducible RAPD patterns were obtained. Several publications have discussed problems of reproducibility associated with RAPD markers $(1,16,18)$. One of the major factors that affect reproducibility is the composition of the reaction mixture, which can vary from one experiment to another. This problem can be alleviated through the use of master mixes or precombined PCR

\section{LITERATURE CITED}

1. Arnau, J., Housego, A. P., and Oliver, R. P. 1994 The use of RAPD markers in the genetic analysis of the plant pathogenic fungus Cladosporium fulvum. Curr. Genet. 25:438444.

2. Baccino, G. M., and Fitipaldo, J. J. 1984 Control Químico post-cosecha de Penicillium expansum y Botrytis cinerea en manzana Red Delicious y Granny Smith. Tesis de Ingeniero Agrónomo. Facultad de Agronomía, Universidad de la República, Montevideo, Uruguay.

3. Boysen, M. E., Jacobsson, K-G., and Schnürer, J. 2000. Molecular identification of species from the Penicillium roqueforti group associated with spoiled animal feed. Appl. Environ. Microbiol. 66:1523-1526.

4. Brause, A. R., Trucksess, M. W, Thomas, F. S., and Page, S. W. 1996. Determination of patulin in apple juice by liquid chromatography. Collaborative study. J. AOAC Int. 79(2):452-455.

5. Castle, A., Speranzini, D., Rghei, N., Alm, G., Rinker, D. and Bisset, J. 1998. Morphological and molecular identification of Trichoderma 
isolates on North American mushroom farms. Appl. Environ. Microbiol. 64:133-137.

6. Chen, X., Romaine, Q., Tan, Q., Schlagnhaufer, B., Ospina-Giraldo, M., Royse, D., and Huff, D. 1999. PCR-Based genotyping of epidemic and preepidemic Trichoderma isolates associated with green mold of Agaricus bisporus. Appl. Environ. Microbiol. 65:26742678.

7. De los Santos, M., Martinez, A., and Rossini, M. 1990. Situación de la Resistencia de Penicillium a Fungicidas Utilizados en Postcosecha de Manzana. Tesis de Ingeniero Agrónomo. Universidad de la República, Facultad de Agronomía, Montevideo, Uruguay.

8. Dupont, J., Magnin, S., Marti, A., and Brousse, M. 1999. Molecular tools for identification of Penicillium starter cultures used in food industry. Int. J. Food Microbiol. 49:109118.

9. Frisvad, J. C. 1981. Physiological criteria and mycotoxin production as aids in identification of common asymmetric penicillia. Appl. Environ. Microbiol. 41:568-579.

10. Frisvad, J. C., and Filtenborg, O. 1983. Classification of terverticillate Penicillia based on profiles of mycotoxins and other secondary metabolites. Appl. Environ. Microbiol. 46:1301-1310

11. Jiménez, M., Mateo, R., Querol, A., Mateo, J., and Hernández, E. 1990. Differentiation of Penicillium griseofulvum Dierckx isolates by enzyme assays and by patulin and griseofulvin analyses. Appl. Environ. Microbiol. 56:3718-3722

12. Jones, A. L., and Aldwinckle, H. S. 1990. Compendium of Apple and Pear Diseases. American Phytopathological Society Press, St. Paul, MN.

13. Kubelik, A. R., and Szabo, L. J. 1995. High-
GC primers are useful in RAPD analysis of fungi. Curr. Genet. 28:384-389.

14. Laroche, A., Gaudet, D. A., Schaalje, G. B., Erickson, R. S., and Ginns, J. 1995. Grouping and identification of low temperature basidiomycetes using mating, RAPD and RFLP analyses. Mycol. Res. 99:297-310.

15. Latorre, B., ed. 1989. Fungicidas y nematicidas; avances y aplicabilidad. Facultad de Agronomía, Pontificia Universidad Católica de Chile, Santiago, Chile.

16. Micheli, M. R., Bova, R., Pascale, E., and D'Ambrosio, E. 1994. Reproducible DNA fingerprinting with the random amplified polymorphic DNA (RAPD) method. Nucleic Acids Res. 22:1921-1922.

17. Paterson, R. R. M., and Bridge, P. D. 1994. Biochemical Techniques for Filamentous Fungi, International Mycological Institute Technical Handbooks No. 1. CAB International, Wallingford, UK.

18. Penner, G. A., Bush, A., Wise, R., Kim, W., Domier, I., Kashs, K., Laroche, A., Scoles, G., Molnar, S. J., and Fedak, G. 1993. Reproducibility of random amplified polymorphic DNA. PCR Methods Appl. 2:341-345.

19. Pitt, J. I. 1988. A Laboratory Guide to Common Penicillium Species, 2nd ed. CSIRO Division of Food Processing, North Ryde, New South Wales, Australia.

20. Pitt, J. I., and Hocking, A. D. 1997. Fungi and Food Spoilage. Chapman \& Hall, New York.

21. Ramirez, C. 1983. Manual and Atlas of the Penicillia. Elsevier Biomedical Press, Amsterdam.

22. Raper, K. B., and Thom, C. 1949. A Manual of the Penicillia. William and Wilkins Co., Baltimore.

23. Raeder, U., and Broda, P. 1985. Rapid preparation of DNA from filamentous fungi. Lett. Appl. Microbiol. 1:17-20
24. Rohlf, F. J., 1993. NTSYS.pc Numerica Taxonomy and Multivariate Analysis System. State University of New York at Stony Brook, New York.

25. Rosenberger, D. A. 1991. Pathogenicity and benzimidazole resistance in Penicillium species recovered from flotation tanks in apple packinghouses. Plant Dis. 75:712-715.

26. Rosengurtt de Verdier, Z., and Riccio de Machado, O. 1981 Estudio de diferentes problemas sanitarios que se presentan en la manzana Red Deliciosa comercializada en el Mercado Modelo. MAP, Dirección de Sanidad Vegetal, Montevideo, Uruguay.

27. Samson, R., Ribera, F., Sanchis, V., and Canela, R. 1995. Introduction to food-borne fungi. Centraalbureau voor Schimmelcultures, Baarn, Netherlands.

28. Sneath, P. H. A., and Sokal, R. R. 1973. Numerical Taxonomy. The Principles and Practice of Numerical Classification. Freeman, San Francisco.

29. Soll, D. R. 2000. The ins and outs of DNA fingerprinting the infectious fungi. Clin. Microbiol. Rev. 13:332-370.

30. Thompson, J. R., and Latorre, B. A. 1999. Characterization of Botrytis cinerea from table grapes in Chile using RAPD-PCR. Plant Dis. 83:1090-1094.

31. Vero, S., Vázquez, A., Cerdeiras, M. P., and Soubes, M. 1999. A rapid TLC-scanning method for the determination of patulin in apple products. J. Planar Chromatogr. 12:172 174.

32. White, T. J., Bruns, T., Lee, S., and Taylor, J. 1990. Amplification and direct sequencing of fungal ribosomal RNA genes for phylogenetics. Pages 315-322 in: PCR Protocols: A Guide to Methods and Applications. M. A Innis, D. H. Gelfand, J. J Sninsky, and T. J. White, eds. Academic Press, San Diego, CA. 